\title{
Relationship between testicular inhibin content and serum FSH concentrations in rats after bilateral efferent duct ligation*
}

\author{
C. L. Au†, D. M. Robertson and D. M. de Kretser \\ Department of Anatomy, Monash University, Clayton, Victoria 3168, Australia
}

\begin{abstract}
Summary. The testicular inhibin content showed an initial increase in the first 2-3 days after bilateral ligation of the efferent ducts of rats, followed by a subsequent decline to levels significantly below normal by 14 days, and reached $25 \%$ of control values at 42 days. Serum concentrations of FSH and LH were significantly increased at Day 6-7 after treatment and were still elevated after 42 days. The decline in testicular inhibin content at times associated with elevated FSH concentrations is consistent with the hypothesis of inhibin being involved in the feedback control of FSH secretion.
\end{abstract}

\section{Introduction}

Ligation of the efferent ducts of the mammalian testis results in an initial accumulation of fluid and secretory products in the seminiferous tubules, and a subsequent decline in testicular weight and atrophy of the seminiferous epithelium (Smith, 1962; Setchell, 1970; Anton, 1979). The latter changes are thought to be the result of pressure damage caused by fluid accumulation in the seminiferous tubule. Before the seminiferous epithelium completely degenerates, serum FSH concentrations are already significantly elevated despite normal serum testosterone concentrations and no changes in the weight of accessory sex glands (Davies, Main \& Setchell, 1978; Main, Davies \& Setchell, 1978; Collins, Collins, McNeilly \& Tsang, 1978; Morris, 1979). These findings suggest a reduced feedback inhibition of pituitary FSH secretion by testicular inhibin (Setchell, Davies \& Main, 1977; Main et al., 1978; Collins et al., 1978; Morris, 1979; Le Lannou, Chambon \& Le Calve, 1979). At present, the assay systems for inhibin are too insensitive to measure levels in male rat plasma ( $\mathrm{Au}$, Robertson \& de Kretser, 1984), but the presence of inhibin in both testicular interstitial fluid and rete testis fluid suggests that, under normal conditions, inhibin release from the Sertoli cells is bidirectional (Setchell \& Sirinathsinghji, 1972; Au et al., 1984). It has been proposed that, after efferent duct ligation, either the route of inhibin passage to the excurrent duct system where it is reabsorbed and gains entry into the general circulation is blocked (Franchimont, Chari, Hazee-Hagelstein, Debruche \& Duraiswami, 1977; Le Lannou et al., 1979), or the direct release of inhibin into the testicular lymphatics and/or venous drainage is reduced following a decline in inhibin production by the Sertoli cells of the degenerating seminiferous epithelium (Davies et al., 1978; Morris, 1979). In the present study, testicular inhibin content in rats after bilateral efferent duct ligation was measured by an in-vitro inhibin bioassay and related to the corresponding changes in serum gonadotrophins.

\section{Materials and Methods}

Bilateral efferent duct ligation or sham-operation was performed on 90 -day-old rats according to the procedure of Smith (1962). In Exp. 1, 7 animals from each group were killed at intervals of 3, 7,

* Reprint requests to Professor D. M. de Kretser.

† Present address: Department of Physiology, Chinese University of Hong Kong, Shatin, N.T. Hong Kong. 
14, 28 and 42 days after ligation. In Exp. 2, the effects of bilateral efferent duct ligation were examined every $24 \mathrm{~h}$ in the first week after treatment. High-speed supernatants of homogenates of the paired testes from individual animals were charcoal-extracted and then bioassayed for inhibin using rat pituitary cells in culture as previously described (Au et al., 1983). The activity was expressed in terms of the reference standard, an ovine testicular lymph preparation with an assigned potency of $1 \mathrm{U} / \mathrm{mg}$ (Eddie, Baker, Higginson \& Hudson, 1979). The sensitivity of the inhibin bioassay was 10 units/testis. Serum FSH and LH concentrations were measured by specific radioimmunoassays whose characteristics have been previously described (Au et al., 1983). FSH levels are expressed in terms of NIAMDD-rat-FSH-RP1 and LH levels in terms of NIAMDD-ratL.H-I ${ }_{5}$. All samples were measured in a single assay and the intra-assay coefficients of variation were 5 and $6 \%$ for $\mathrm{FSH}$ and $\mathrm{LH}$, respectively. The sensitivities of the FSH and $\mathrm{LH}$ radioimmunoassays were 75 and $0 \cdot 10 \mathrm{ng} / \mathrm{ml}$ respectively. Testicular weight and inhibin content and serum gonadotrophin concentrations in the treated rats were compared to those of the corresponding controls by Student's $t$ test.

\section{Results}

\section{Testicular weight and inhibin content}

In Exp. 1, the weight of the ligated testes was significantly higher $(132 \% ; P<0.005)$ at Day 3 , then decreased to normal at Day 7, and remained at $31-40 \%$ below control values $(P<0.001)$ from Day 14 to Day 42 (Table 1). The inhibin content in the ligated testes showed similar changes (Table 1); an initial increase at Day $3(296 \% ; P<0.001)$, was followed by a decline at Day 7 to levels which were still higher than $(137 \%)$, but not significantly different from those of the controls. At Day 14 , there was a significant reduction $(P<0.001)$ in the inhibin content which was only $25 \%$ of normal levels at Day 42.

In Exp. 2, fluid and inhibin accumulation in the ligated testes declined earlier than in Exp. 1 (Text-fig. 1). Testicular weight showed an initial increase $(P<0.001)$ at Days 1 and 2 after ligation, and remained in the normal range until Day 7 when a significant reduction $(P<0.025)$ occurred. Similar changes in the inhibin content (Text-fig. 1) were also noted except at Day 3 when normal testicular weight was associated with significantly $(P<0.025)$ elevated inhibin activity in the ligated testes, and at Day 7 when the testicular inhibin content was still not significantly different from that of controls.

Table 1. Effects of bilateral efferent duct ligation (EDL) on testis weight, testicular inhibin content and serum gonadotrophin concentrations in rats after 3-42 days of treatment

\begin{tabular}{llccccc}
\hline & & \multicolumn{5}{c}{ Days after ligation } \\
\cline { 3 - 7 } & Treatment & \multicolumn{1}{c}{3} & \multicolumn{1}{c}{7} & \multicolumn{1}{c}{14} & 28 & 42 \\
\hline Testis weight $(\mathrm{g})$ & Control & $2 \cdot 98 \pm 0 \cdot 06$ & $3 \cdot 29 \pm 0 \cdot 09$ & $3 \cdot 43 \pm 0 \cdot 12$ & $3 \cdot 73 \pm 0 \cdot 11$ & $3 \cdot 25 \pm 0 \cdot 07$ \\
& EDL & $3 \cdot 94 \pm 0 \cdot 21^{* *}$ & $3 \cdot 03 \pm 0 \cdot 19$ & $2 \cdot 05 \pm 0 \cdot 25^{* * *}$ & $2 \cdot 30 \pm 0 \cdot 10^{* * *}$ & $2 \cdot 24 \pm 0 \cdot 17^{* * *}$ \\
\hline Testicular & Control & $228 \pm 29$ & $230 \pm 16$ & $209 \pm 25$ & $254 \pm 20$ & $261 \pm 17$ \\
inhibin content (U) & EDL & $674 \pm 43^{* * *}$ & $316 \pm 64$ & $121 \pm 18^{* *}$ & $111 \pm 11^{* * *}$ & $59 \pm 9^{* * *}$ \\
\hline Serum FSH (ng/ml) & Control & $341 \pm 20$ & $314 \pm 29$ & $376 \pm 36$ & $310 \pm 37$ & $340 \pm 43$ \\
& EDL & $458 \pm 103$ & $516 \pm 19^{* * *}$ & $742 \pm 27^{* * *}$ & $599 \pm 65^{* *}$ & $461 \pm 30^{*}$ \\
\hline Serum LH (ng/ml) & Control & $0 \cdot 58 \pm 0 \cdot 12$ & $0 \cdot 81 \pm 0 \cdot 09$ & $0 \cdot 57 \pm 0 \cdot 09$ & $0 \cdot 72 \pm 0 \cdot 07$ & $0 \cdot 76 \pm 0 \cdot 08$ \\
& EDL & $0 \cdot 65 \pm 0 \cdot 15$ & $1 \cdot 24 \pm 0 \cdot 13^{*}$ & $1 \cdot 52 \pm 0 \cdot 22^{* *}$ & $1 \cdot 42 \pm 0 \cdot 07^{* * *}$ & $1 \cdot 54 \pm 0 \cdot 17^{* *}$ \\
\hline
\end{tabular}



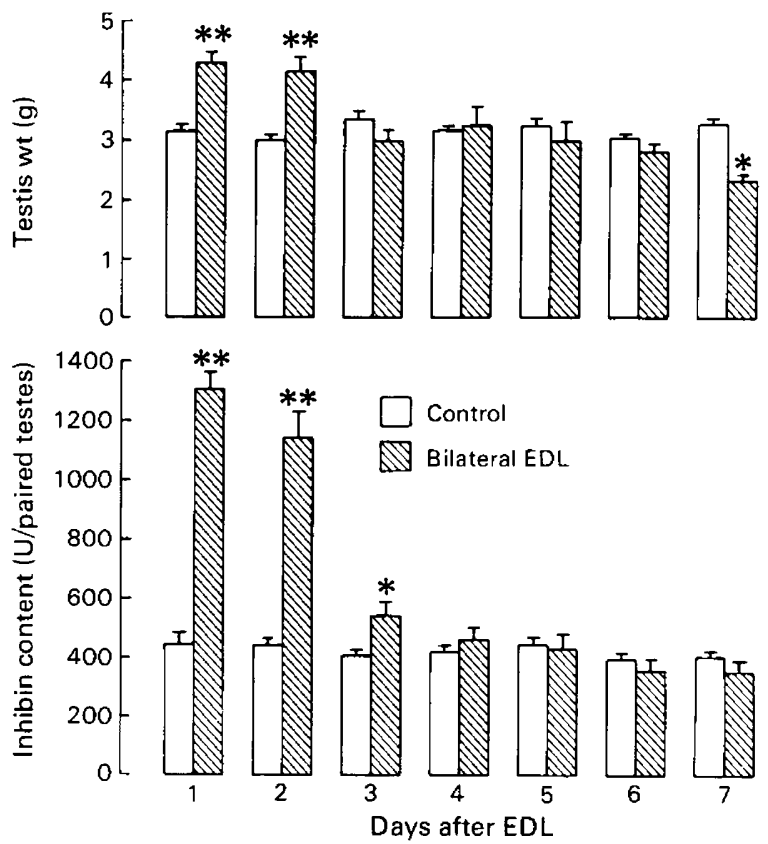

Text-fig. 1. Changes in rat testicular weight with time after bilateral efferent duct ligation (EDL); the difference between the control and experimental group represents the ability of the seminiferous tubules to secrete fluid. The changes in the inhibin content with time after ligation are also shown. Values are mean \pm s.e.m. for 7 rats/group. ${ }^{*} P<0.01 ;{ }^{*} P<0.001$ compared to control value.

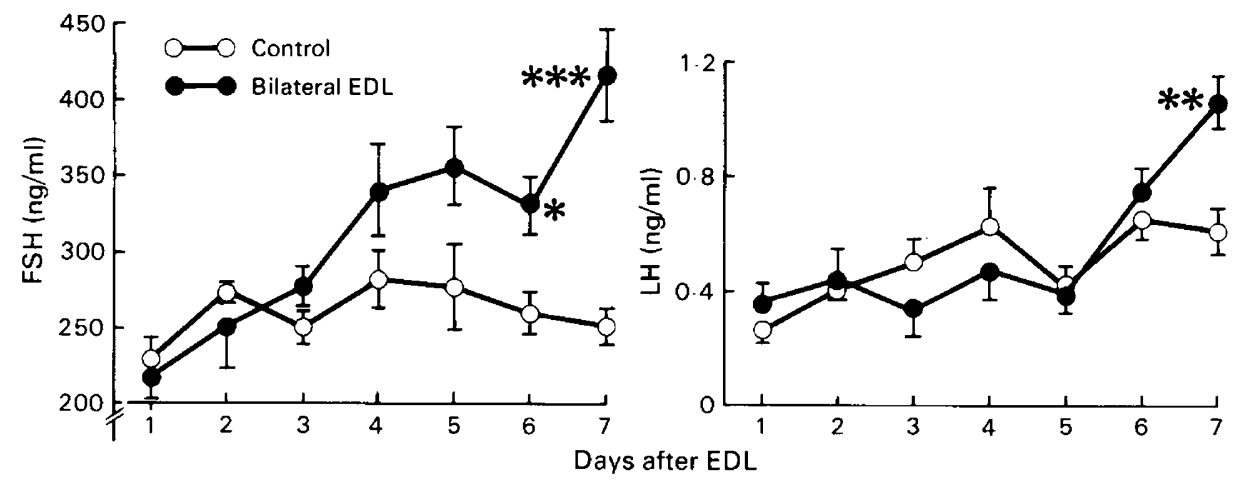

Text-fig. 2. Changes in the concentrations of serum FSH and LH after bilateral efferent duct ligation of rats. Values are mean \pm s.e.m. for 7 rats/group. ${ }^{*} P<0.025 ;{ }^{* *} P<0.001$ compared to control value.

\section{Serum FSH and LH concentrations}

In both experiments (Table 1; Text-fig. 2) serum FSH and LH concentrations were significantly elevated $(P<0.01)$ from Days 6 and 7 after ligation and for up to 42 days (Table 1). If the data for inhibin, FSH and LH from 7 to 42 days are taken together, FSH and LH concentrations were inversely correlated to inhibin values (FSH $v$ s inhibin, $r=-0.35, P<0.01$; LH $v$ s inhibin; $r=$ $-0.46, P<0.001 ; n=54)$. 


\section{Discussion}

This study demonstrated that, after bilateral efferent duct ligation in rats, the testicular inhibin content showed an initial increase for 1-3 days followed by a subsequent decline. The decline parallels the ability of the seminiferous tubule to secrete fluid after efferent duct ligation and would be consistent with the view that both products are secreted by the Sertoli cell (Steinberger \& Steinberger, 1976; Waites \& Gladwell, 1982; Le Gac \& de Kretser, 1982; Verhoeven \& Franchimont, 1983). Furthermore, the later changes in FSH and inhibin are consistent with a role for inhibin involved in the feedback control of pituitary FSH secretion, since the decrease in testicular inhibin content was accompanied by a rise in serum FSH. The decline in the testicular inhibin content 14 days after efferent duct ligation is consistent with the concept that this procedure results in pressure atrophy of the seminiferous epithelium and impaired Sertoli cell function (Smith, 1962; Risbridger, Kerr, Peake \& de Kretser, 1981b).

The changes in FSH and inhibin after efferent duct ligation are not always inversely related particularly in the first week. In the first 2 days, significantly elevated concentrations of inhibin were associated with no changes in serum FSH whereas after 6-7 days FSH levels rise although testicular inhibin content remains normal. The increase in inhibin content of the testis for $48 \mathrm{~h}$ after efferent duct ligation indicates that the inhibin secreted into the seminiferous tubule lumen is trapped. However, the accumulated inhibin does not appear to influence FSH secretion significantly, probably because of the integrity of the blood-testis barrier (Nykanen \& Kormano, 1978; Osman \& Ploen, 1978; Osman, 1978) and the failure of the raised intratubular levels to effect an increase in the secretion of inhibin across the base of the Sertoli cell into testicular lymphatics (Au et al., 1984). Nevertheless, others have suggested that the passage of inhibin into rete testis fluid and its subsequent absorption represents an important pathway by which inhibin reaches the circulation (Le Lannou et al., 1979; Lipner \& Rush, 1981). The failure of FSH levels to rise immediately after efferent duct ligation would raise some doubt as to the importance of this exit pathway. Similar conclusions were reached by other investigators who noted inconsistent changes in serum FSH levels in hemicastrated rams in which chronic cannulation of the rete testes drained the seminiferous tubule fluid away from the epididymis (Walton, Evins \& Waites, 1978; Blanc et al., 1978; Davies et al., 1979).

However, opposite conclusions can be reached from an examination of the data during Days 6-7 of Exp. 2 when FSH values were elevated in the presence of normal testicular inhibin levels. Based on these results it could be argued that efferent duct ligation prevented the absorption of inhibin at an extratesticular site, resulting in the failure of normal testicular inhibin levels to maintain control of FSH. The data and techniques used in the present study are unable to demonstrate conclusively the major pathway by which inhibin gains access to the circulation. Since inhibin activity is present in testicular interstitial fluid and lymph in higher concentrations than in plasma (Baker et al., 1978; Krause, 1978; Au et al., 1984), inhibin must be secreted across the basal aspect of the Sertoli cells as well as their luminal surface. This bidirectional release has also been noted for androgen-binding protein, another Sertoli cell product (Gunsalus, Musto \& Bardin, 1978, 1980). Until assays with sufficient sensitivity to measure inhibin levels in blood are available, it will not be possible to follow acute changes in the circulating concentrations of inhibin after efferent duct ligation.

The present study also confirms that serum $\mathrm{LH}$ levels rise after bilateral efferent duct ligation in rats (Collins et al., 1978; Risbridger et al., 198 l b). It could be argued that this rise in LH is due to the decline in testicular inhibin levels since some investigators have noted the suppressive effect of inhibin-containing extracts on LH secretion, particularly at high doses (Setchell et al., 1977; Franchimont et al., 1977; Lee et al., 1979; de Jong, Smith, \& van der Molen, 1979). However, alterations in Leydig cell function have been shown after efferent duct ligation in rats and they consist of hypertrophy, hyperresponsivity to hCG in vitro and loss of LH receptors (Risbridger $e t$ al., 198 l b). These changes have been interpreted as evidence of a local control of Leydig cells by the 
seminiferous tubules (Risbridger et al., 1981b; de Kretser, 1982). The elevated serum LH concentrations after bilateral efferent duct ligation are accompanied by normal serum testosterone values and may indicate a state of compensated Leydig cell failure, resembling changes seen in other models of spermatogenic damage such as fetal irradiation, vitamin A deficiency and cryptorchidism (see review by de Kretser, 1982; Rich, Kerr \& de Kretser, 1979; Risbridger, Kerr \& de Kretser, 1981a). The failure of testosterone secretion to rise in the presence of elevated LH concentrations may result from a combination of the effects of decreased blood flow through the testis and the reduced numbers of LH receptors on the Leydig cells after testicular damage (de Kretser, 1982).

We thank Mrs S. Ellis, Mr R. Allen and Mrs J. Trewin for technical assistance, and the Rat Pituitary Hormone Distribution Program of the NIADDK for the gonadotrophin radioimmunoassay kits. These studies were supported by grants from the National Health and Medical Research Council of Australia.

\section{References}

Anton, E. (1979) Early ultrastructural changes in the rat testis after ductuli efferentes ligation. Fert. Steril. 31, 187-194.

Au, C.L., Robertson, D.M. \& de Kretser, D.M. (1983) In vitro bioassay of inhibin in testes of normal and cryptorchid rats. Endocrinology 112, 239-244.

Au, C.L., Robertson, D.M. \& de Kretser, D.M. (1984) An in-vivo method for estimating inhibin production by adult rat testes. J. Reprod. Fert. 71, 259-265.

Baker, H.W.G., Burger, H.G., de Kretser, D.M., Eddie, L.W., Higginson, R.E., Hudson, B. \& Lee, V.W.K. (1978) Studies on purification of inhibin from ovine testicular secretions using an in vitro bioassay. Int. $J$. Androl., Suppl. 2, 115-123.

Blanc, M.R., Dacheux, J.L., Cahoreau, C., Courot, M., Hochereau-de Reviers, M.Th., Lacroix, A. \& Pisselet, C.L. (1978) The role of testicular fluid on plasma levels of FSH and LH in the ram. Annls Biol. anim. Biochim. Biophys. 19, 1027-1032.

Collins, P.M., Collins, W.P., McNeilly, A.S. \& Tsang, W.N. (1978) Plasma FSH, LH and testosterone levels in the male rat during degeneration of the germinal epithelium caused by severe heat treatment or ligation of the vasa efferentia. $J$. Reprod. Fert. 54, 285-291.

Davies, R.V., Main, S.J. \& Setchell, B.P. (1978) Inhibin: evidence for its existence, method of bioassay and nature of the active material. Int. J. Androl., Suppl. 2, $102-114$

Davies, R.V., Main, S.J. \& Setchell, B.P. (1979) Inhibin in ram rete testis fluid. J. Reprod. Fert., Suppl. 26, 87 95

de Jong, F.H., Smith, S.D. \& van der Molen, H.J. (1979) Bioassay of inhibin-like activity using pituitary cells in vitro. $J$. Endocr. 80, 91-102.

de Kretser, D.M. (1982) Sertoli cell-Leydig cell interaction in the regulation of testicular function. Int. J. Androl., Suppl. 5, 11-17.

Eddie, L.W., Baker, H.W.G., Higginson, R.E. \& Hudson, B. (1979) A bioassay for inhibin using pituitary cell cultures. $J$. Endocr. 81, 49-60.

Franchimont, P., Chari, S., Hazee-Hagelstein, M.T., Debruche, M.L. \& Duraiswami, S. (1977) Evidence for the existence of inhibin. In The Testis of Normal and Infertile Men, pp. 253-270. Eds P. Troen \& H. Nankin. Raven Press, New York.

Gunsalus, G.L., Musto, N.A. \& Bardin, C.W. (1978) Factors affecting blood levels of androgen binding protein in the rat. Int. J. Androl., Suppl. 2, 482-493.

Gunsalus, G.L., Musto, N.A. \& Bardin, C.W. (1980) Bidirectional release of a Sertoli cell product, androgen binding protein, into the blood and seminiferous tubule. In Testicular Development, Structure and Function, pp. 291-297. Eds A. Steinberger \& E. Steinberger. Raven Press, New York.

Krause, W. (1978) Inhibin-like effects of interstitial testis fluid: effects on serum FSH and androgen-binding protein in epididymis. Endokrinologie 71, 129-134.

Lee, V.W.K., Scott, R.S., Dobos, M., Zachariah, E., de Kretser, D.M. \& Burger, H.G. (1979) Inhibin and the biological significance of FSH suppression. In Recent Advances in Reproduction and Regulation of Fertility, pp. 241-252. Ed. G. P. Talwar. Elsevier/NorthHolland Biomedical Press, Amsterdam.

Le Gac, F. \& de Kretser, D.M. (1982) Inhibin production by Sertoli cell cultures. Molec. cell. Endocr. 28, 487498.

Le Lannou, D., Chambon, X. \& Le Calve, M. (1979) Role of the epididymis in reabsorption of inhibin in rat. $J$. Reprod. Fert., Suppl. 26, 117-121.

Lipner, H. \& Rush, M.E. (1981) Site of absorption of testicular inhibin. Fedn Proc. Fedn Am. Socs exp. Biol. 40, Abstr. 1384.

Main, S.J., Davies, R.V. \& Setchell, B.P. (1978) Feedback control by the testis of gonadotrophin secretion: an examination of the inhibin hypothesis. J. Endocr. 79, 255-270.

Morris, I.D. (1979) Effect on gonadotrophin secretion of blockage of the ductuli efferentes in the normal and androgen-deprived rat. $J$. Reprod. Fert. 57, 469-475.

Nykanen, M. \& Kormano, M. (1978) Early effects of efferent duct ligation on the rat rete testis. Int. $J$. Androl. 1, 225-234.

Osman, D.I. (1978) The ultrastructure of the rete testis and its permeability barrier before and after efferent duct ligation. Int. J. Androl. 1, 357-370. 
Osman, D.I. \& Ploen, L. (1978) The terminal segment of the seminiferous tubules and the blood-testis barrier before and after efferent ductule ligation in the rat. Int. J. Androl. 1, 235-249.

Rich, K.A., Kerr, J.B. \& de Kretser, D.M. (1979) Evidence for Leydig cell dysfunction in rats with seminiferous tubule damage. Molec. cell. Endocr. 13, 123-135.

Risbridger, G.P., Kerr, J.B. \& de Kretser, D.M. (1981a) Evaluation of Leydig cell function and gonadotrophin binding in unilateral and bilateral cryptorchidism: evidence for local control of Leydig cell function by the seminiferous tubule. Biol. Reprod. 24, 534-540.

Risbridger, G.P., Kerr, J.B., Peake, R.A. \& de Kretser, D.M. (1981b) An assessment of Leydig cell function after bilateral or unilateral efferent duct ligation: further evidence for local control of Leydig cell function. Endocrinology 109, 1234-1241.

Setchell, B.P. (1970) Testicular blood supply, lymphatic drainage and secretion of fluid. In The Testis, Vol. I, pp. 101-239. Eds A. Johnson, W. Gomes \& N. VanDemark. Academic Press, New York.
Setchell, B.P. \& Sirinathsinghji, D.J. (1972) Antigonadotrophic activity in rete testis fluid, a possible "inhibin". J. Endocr. 53, lx-lxi, Abstr.

Setchell, B.P., Davies, R.V. \& Main, S.J. (1977) Inhibin. In The Testis, Vol. IV. pp. 189-238. Eds A. Johnson \& W. Gomes. Academic Press, New York.

Smith, G. (1962) The effects of ligation of the vasa efferentia and vasectomy on testicular function in the adult rat. J. Endocr. 23, 385-399.

Steinberger, A. \& Steinberger, E. (1976) Secretion of an FSH-inhibiting factor by cultured Sertoli cells. Endocrinology 99, 918-921.

Verhoeven, G. \& Franchimont, P. (1983) Regulation of inhibin secretion by Sertoli cell-enriched cultures. Acta endocr., Copenh. 102, 136-143.

Waites, G.M.H. \& Gladwell, R.T. (1982) Physiological significance of fluid secretion in the testis and bloodtestis barrier. Physiol. Rev. 62, 624-671.

Walton, J.S., Evins, J.D. \& Waites, G.M.H. (1978) Effect of chronic removal of testicular fluid on the release of follicle-stimulating hormone in hemi-castrated rams. J. Endocr. 27, 421-422.

Received 19 January 1984 